\title{
Implementing Task-Based Instruction to Facilitate Language Learning: Moving Away from Theory
}

\author{
Aileen Griffiths \\ Atma Jaya Catholic University, Jakarta
}

\begin{abstract}
The use of tasks has gained growing acceptance in the field of language teaching. In the task-based teaching, the organization of the language lassroom is learner-centered and the learning activities involve communicative language use. This paper discusses task-based teaching by presenting a brief overview of its underlying rationales. The rationales for infcoporating task-based activities are dirived from the psycholinguistic and pedagogical perpectives. Some practical insights in this paper might be useful for English teachers and language experts.
\end{abstract}

Key words: task-based instruction, language learning, communicative language use, form focused instruction.

In recent years, the increasing popularity of task-based teaching has motivated a shift in the language classroom organization from the traditional teacher-fronted to a learner-centered organization. In fact, the use of tasks has gained growing acceptance in the language teaching field as tasks have been seen principally as devices to allow learners to practice using the target language as a tool of communication (Loschky and BleyVroman, 1993).

In light of this current trend, the concept of task has been variously defined in a number of publications dealing with this subject. However, according to Nunan (1992), all the definitions basically share one thing in common; they imply that tasks involve communicative language use in which the participants' attention is focused on meaning rather that linguistic structure. In addition, Pica, Kanagy, and Falodun (1993) point out that within various definitions of task which exist in the literature, two recurrent features stand out; the first is that tasks are oriented toward goals, and the second is that tasks entail an active role of the participants. 
Even though the word "task" might not be a novel term for English teachers in Indonesia as a result of the implementation of communicative approach, making use of tasks as the basis for classroom instruction is, most probably, still a vague concept. This article, therefore, attempts to provide a better understanding of task-based teaching by presenting a brief overview of its underlying rationales. In addition, this article also strives to offer some practical insights for English teachers and language experts in Indonesia by discussing the foreseeable problems and challenges in the implementation of task-based teaching in secondary-school context.

\section{WHY TASK-BASED TEACHING?}

In the midst of the development of task-based pedagogy, language experts and methodologists have also been providing various justifications in favor of the use of task based activities. In the following sections, rationales for incorporating task-based activities from the psycholinguistic and pedagogical perspectives will be discussed.

\section{PSYCHOLINGUISTIC RATIONALES}

The first psycholinguistic significance underlying the proposition of task-based activities is based upon the role of comprehensible input in Second Language Acquisition (SLA). Krashen, as quoted by Richards and Rodgers (1986), proposes the Input Hypothesis, stating that learners should be exposed to language input that is slightly beyond their current level of competence. Clarifying the significance of his theory, Krashen further argues that the more language that the learners hear and understand or the more comprehensible input they receive, the faster and better they learn. In other words, learners should be continuously exposed to input (i.e. tasks), modified in a variety of ways to make it comprehensible.

Another psycholinguistic rationale supporting the use of tasks is the ample opportunity available for negotiation. According to Crookes and Gass (1993), language acquisition is closely related to conscious attention; without it acquisition cannot take place. They further argue that in order for input to become useful to a learner, it must first be 'noticed.' What negotiation then does is focusing a learner's attention on the part of her/ his utterance which has not been successful. Thus, negotiation can be viewed as a trigger for acquisition. Indeed, research conducted by Long and Porter (1985) as well as Pica and Doughty (1983) reveal that more negotiated interaction (i.e. clarification requests, confirmation and comprehension checks), more turn-taking and more repetition (self and other) would occur in the group task-based activities than in the teacher-fronted ones.

The last psycholinguistic rationale is the amount of correction. Long and Porter (1985) state that, although learners cannot provide each other with the accurate grammatical and sociolinguistic input that a native speaker can, they still can offer each other genuine communicative practice, including the negotiation for meaning that is believed to aid SLA. In this case, Long (1989) also asserts that classroom studies have found that the frequencies of other-correction and completions by students are, in fact, higher in group work than in teacher-fronted teaching.

\section{PEDAGOGICAL RATTONALES}

Long and Porter (1985) point out that the main reason for low achievement by language learners is simply because they do not have cnough time to practice the new language as a result of the teacher's predominant mode of instruction or lockstep. Therefore, they further argue that the use of group/pair work will not only increase the quantity of language practice opportunities, but also improve the quality of students talk. Given the fact that the teaching-learning activities conducted using the task-based underlying principles utilize group/pair work as their main classroom organization, quite clearly, Long and Porter's argument justify the use of task-based activities.

Another advantage of using tasks is that it helps individualize instruction, potentially allowing students to work at their own pace, perhaps using different materials (Long, 1989). Long further states that students can, therefore, receive instruction more closely tailored to their needs and individual differences in such areas as aptitude, interests, cognitive style, cultural background, and language proficiency.

In addition, task completed in groups also proves to be beneficial in promoting a positive affective climate as, in contrast with the public atmosphere of lockstep instruction, it provides a relatively friendly setting and a more supportive environment; thus, it is especially valuable to shy or linguistically insecure students (Long and Porter, 1985). In this case, 
Barnes, as cited by Long (1989), asserts that group work, if appropriately organized, can prevent students from the pressure called "audience effect" and provide them with an intimate setting which triggers "exploratory" talk. Regarding this argument, Prabhu (1987) points out that a taskbased classroom is in any case a social situation with its friendship, rivalries, self-images and attitudes, which teachers relate to as well as they can and take into consideration in their management procedures. Therefore, he further affirms that learners' involvement and interest would naturally be promoted.

\section{TASK-BASED TEACHING IN SECONDARY-SCHOOL CONTEXT}

In the implementation of any new language program, problems will always arise. Similarly, if task-based teaching are to be applied in the secondary-school level, we should seriously consider the problems that will occur so that we would be able to readily anticipate them and appropriately deal with them. The following two sections will discuss some of the major foreseeable problems of incorporating task-based teaching as well as the possible solutions and challenges.

\section{FORESEEABLE PROBLEMS}

In relation to implementing process-oriented approaches such as taskbased teaching, Ellis (1996) raises an important issue that should be taken into consideration, i.e. the distinction between English as a Second Language (ESL) and English as a Foreign Language (EFL) situations. He points out that since ESL takes place within an English-speaking country, the students naturally have not only far greater need to communicate, but also the opportunity to immediately test out or practice new language skills in authentic situations. On the contrary, in the EFL situations such as Indonesia, English is taught merely as a subject, just the same as such other subjects as Bahasa Indonesia, Geography, or Mathematics. Therefore, without the reinforcement of an English-speaking environment, English is just a part of the school curriculum, which is normally dictated by the government policy. This will be a downside for our learners because, without the sense of immediate need, they will, to some extent, be less-motivated to learn and practice the target language compared to their peers in the ESL situation.
Another major constraint in incorporating task-based teaching is the English teachers' language proficiency. According to Markee (1997), teachers are key players in any language teaching innovation and thus, they play a crucial role in its success or lack of it. In conducting taskbased activities, there is no doubt that proper mastery of spoken English is required. Nonetheless, with all due respect to all Indonesian English teachers, we cannot deny the fact that the teachers' oral proficiency varies from excellent to poor. In fact, limited competence in spoken English is still quite common among the Indonesian English teachers.

Next, conflicts concerning the adoption of task-based teaching will, most probably, be rooted in our society's philosophical belief. Regarding this issue, Stewart and Bennett (1991), assert that in contrast to American families which encourage individuality and autonomy to their children at a very early age, extreme form of personal preference would not be cultivated or tolerated in Asian families. While children in the American families are encouraged to make decisions for themselves, develop their own opinions, and solve their own problems, the Asian families do not allow their children to challenge the authority of their parents and elders. The complication of this condition will be twofold. On the one hand, students are not used to speaking up and expressing their opinions in class, and as a result might feel uncomfortable being asked to actively participate in the teaching-learning activities. On the other hand, in order to effectively maintain task-based activities, teachers are expected to make some organizational changes (Doughty and Pica, 1986); being used to be educated the same way as their students, they might feel uncomfortable because the changes can cause redistribution of power and authority. These adverse circumstances will definitely affect the practice of taskbased teaching in the Asian countries, including Indonesia.

Furthermore, some logistical constraints that should also be taken into account are the issues of class size and the availability of innovative teaching resources and materials (Tickoo, 1996), which are undeniably true when it comes to the secondary school situation in Indonesia. With regard to the first constraint, the size of class (about 40-50 students) and the furniture available (either unmovable or extremely heavy) make the organization of group work difficult. As for the latter constraint, Tickoo (1996) maintains that it is of utmost importance to incorporate instructional materials that intrinsically appeal to learner ages, abilities, and interests, encourage learner involvement, and help build learner autonomy. Never- 
theless, so far, the available English textbooks have not fully met such requirements yet.

Apart from the above-mentioned constraints, various syllabus-related problems, such as what kind of task should be used and how to use it, should also be carefully considered, as Brown (1994) affirms that tasks are not simply a set of activities thrown haphazardly into our classrooms for the students to complete.

\section{POSSIBLE SOLUTIONS AND CHALLENGES}

In secondary schools in Indonesia, even though Communicative Language Teaching has been formally put into practice through the socalled Curriculum 1994, the day-to-day classroom application is still far from what is supposed to happen in a process-oriented, communicative language class. This discrepancy results from the fact that the traditional, structure-oriented teaching which has been employed for a long period of time still seems to be the most-widely used approach. Owing to this situation, I believe that it will undoubtedly be difficult to swing the pendulum from one extreme to another, i.e. from the form-focused to the meaning-focused, task-based syllabus. Even Brown (1994) claims that it is virtually difficult to purely apply one single syllabus in any teaching context. Therefore, rather than forcing a sudden, drastic change, it will be more rational to move ahead one step at a time. This implies that it would be unsound to adopt 'pure' task-based activities at the expense of other activities; on the contrary, integrating form-focused with meaningfocused instruction could be a worth-considering alternative.

According to Gass (1997), to some extent, form-focused instruction is actually necessary as it is a first step in the modification of a learner's grammar. She further affirms that combining the use of task-based activities with the other more structured activities will create balance between "focusing on form" and "focusing on meaning," rather than forcing the exclusive application of task-based activities. Particularly in EFL contexts such as in Indonesia, this would be a sound justification for the necessity of teaching structure since, according to Ellis (1996), in EFL situations, English teachers are somewhat the main - if not the sole model and provider of experience in the process of learning the target language, and therefore, students' resource of linguistic forms are generally inhibited.
Next, in terms of organizing the teaching-learning activities, the 3Ps approach is, from my point of view, suitable for our context. Skehan (1998) points out that the 3Ps or presentation-based approach which consists of presentation, practice, and production, is one of the more traditional and the most influential approaches of organizing language teaching. He asserts that this approach is widely-used for a couple of reasons; first, it maintains teacher's feeling of professionalism as it places the teacher firmly in charge; and second, it lends itself neatly to accountability since it generates clear and tangible goals, precise syllabuses, and a comfortingly itemizable basis for the evaluation of effectiveness.

Thus, integrating form-focused instruction and task-based activities using the presentation-based approach means acknowledging students' differences in learning styles and personality factors, because this 'balanced' approach leaves sufficient room for the teacher to accommodate all students' needs and wants equally well. A students who is left-brain dominant or inhibited will feel more at ease with the teacher-fronted instruction, while another student who might be right-brain dominant or exrrovert can comfortably resort to the pair/group work, task-based activities.

The nature of tasks is another crucial aspect that should be accounted for. Tasks should be well-chosen in order for the activities to obtain a beneficial result. Thus, teachers should consider the types of tasks used for the their classes. With regard to this, what they need to understand is the distinctions between one-way and two-way tasks, and between open and closed tasks. One-way tasks involve giving information from one participant to another, whereas two-way tasks involve exchanges of information, with each participant holding information crucial to the resolution of the task (Gass, 1997). As for the latter pair, Long (1989) asserts that open task means that there is no predetermined correct solution to the task, but instead a wide range of acceptable solution; closed task, on the contrary, means that the task requires that the participants attempt to reach a single correct solution. However, what kind of tasks can best promote the desired interaction? According to Long and Porter (1985), both two-way tasks and closed tasks produce more negotiation work and more useful negotiation work than one-way and open tasks. 
In addition to being appropriately selected according to its types, task should also be tailored to suit the students' needs, interests, and situations. Supporting this argument, Prabhu (1987) affirms that task should be intelectually challenging enough to maintain students' interest, for that is what will sustain learners' efforts at task completion, focus them on meaning, and as part of that process, engage them in confronting the task's linguistic demands.

Furthermore, Nunan (1993) claims that the roles of teacher and student are two of the major dimensions in task-based instruction. Indeed, teacher role and student role during a task completion should be clearly understood to avoid undesirable consequences. According to Seedhouse (1999), as a rule, the teacher should withdraw after allocating a task to the students, to allow them to manage the interaction themselves; however, he/she should also move around the class, monitoring the interaction and sometimes intervening; if the students are having difficulty with the task, they can ask for help. This implies that the teacher acts as a monitor, a guide, and a facilitator, while the students are the active participants. An added advantage of closely monitoring the students is that it can help reduce the class management problem in large classes.

Aside from the discussed features, various challenges will still remain to be carefully explored. One challenge in incorporating task as a basic element in the design phase is the significant dilemma for selecting and sequencing tasks (Nunan, 1993). It is, however, premature to propose any valid criteria as Kumaravadivelu (1993) argues that selecting and sequencing linguistic input has always been done based on intuitive considerations rather than on any principled and proven way. Suggestion that can be made at this point is simply considering tasks in order of their 'difficulty' and 'structural learnability' (Crookes and Nunan, as cited by Loschky and Bley-Vroman, 1993).

Finally, Fullan, as cited by Markee (1997), suggests that any change in the educational field should consist of changes in the teaching and testing materials, as well as methodological skills and pedagogical values as the core dimensions of teaching and learning. With regard to this opinion, obviously, professional teacher training is indispensable if taskbased teaching is to be adopted. In addition, the secondary-school examination materials should also be seriously looked into and revised so that they will conform and support the full curriculum. Particularly in the EFL context, building and enhancing students' motivation would obviously be a challenging task in itself for the teachers, as without the reinforcement of an English-speaking environment, motivation becomes more a product of the teacher's initiative on the one hand, and the student's will to succeedor fear of failure on the other (Ellis, 1996).

\section{CONCLUSION}

According to Skehan (1993), task-based teaching is one of a numerous attempts to confront one of the dilemmas of language teaching: how, on the one hand, to confront the need to engage naturalistic learning processes, while, on the other, allowing the pedagogic process to be managed in a systematic manner. Considering this argument, it is fairly reasonable to say that task-based teaching is actually not a totally new method; rather it simply puts tasks at the center of one's methodological focus (Brown, 1994), and therefore, understanding the concept would not be too overwhelming to do. However, when it comes to putting it into practice, various variables of the sociocultural, political, logistical, and methodological natures might complicate the process.

In this paper, I would like to invite the audience, as English teachers and language practitioners, to be resourceful but selective in the sense that we should always be willing to accept and adopt new ideas, but at the same time be sensitive to the students' characteristics, needs and interests so that we can make use of any suitable approaches. We should not, by all means, hastily follow the vogue of task-based pedagogy, as badly organized task-based classroom is no better than badly organized teacher-fronted classroom. However, if we do want to adopt task-based teaching, we should realize that the adoption will definitely need not only considerable amount of time and effort, but also the authorities' financial support and progressive thinking.

To sum up, changes in the educational field is virtually unavoidable; however, any innovation is truly a challenge that should be given serious attention and thoughtful consideration as, professionally speaking, all the participants involved are ultimately responsible for the future of the successive generation.

\section{REFERENCES}

Brown, H.D. 1994. Teaching by Principles: An Interactive Approach to Language Pedagogy. Upper Saddle River (NJ): Prentice Hall Regents. 
Crookes, G. and Gass, S. M. (Eds.). 1993. Tasks and Language Learning: Integrating Theory and Practice. Clevedon, Avon: Multilingual Matters, Ltd.

Doughty, C. and Pica, T. 1986. "Information Gap" Tasks: Do they facilitate second language acquisition? TESOL Quarterly, 20(2): 305-325.

Ellis, G. 1996. How culturally appropriate is the communicative approach? ELT Journal, 50(3): 213-218.

Gass, S.M. 1997. Input, Interaction, and the Second Language Learner. Mahwah (NJ): Lawrence Erlbaum Associates, Inc.

In Crookes, G. and Gass, S. M. (Eds.). Tanpa tahun. Tasks and Language Learning: Integrating Theory and Practice. Clevedon, Avon: Multilingual Matters Ltd.

Kumaravadivelu, B. 1993. The Name of Task and the Task on Naming: Methodological Aspects of Task-based Pedagogy. In Crookes, G. and Gass, S.M (Eds.), Task in a Pedagogical Context: Integrating Theory and Practice. Clevedon, Avon: Multilingual Matters, Ltd.

Long, M.H. 1989. Task, Group, and Task-group Interactions. University of Hawaii Working Papers in ESL, 8(2): 1-26.

Long, M.H. and Porter, P.A. 1985. Group Work, Interlanguage Talk, and Second Language Acquisition. TESOL Quarterly, 19(2): 207-228.

Loschky, L. and Bley-Vroman, R. 1993. Grammar and Task-based Methodology. Tanpa penerbit.

Markee, N. P. P. 1997. Managing Curricular Innovation. New York: Cambridge University Press.

Nunan, D. H. 1992. Designing Task for the Communicative Classroom. Cambridge: Cambridge University Press.

Nunan, D. H. 1993. Task-based Syllabus Design: Selecting, Grading, and Sequencing Tasks. In Crookes, G. and Gass, S. M. (Eds.), Task in a Pedagogical Context:Integrating Theory and Practice. Clevedon, Avon: Multilingual Matters Ltd.

Pica, T. and Doughty, C. 1983. The Role of Group Work in Classroom Second Langauge Acquisition. In Faersch, C. and Kasper, G. (Eds.), Foreign Language Learning in a Classroom Setting: Studies in Second Language Acquistion, 7(2): 233-248.

Pica, T., Kanagy, R., and Falodun, J. 1993. Choosing and Using Communicative Tasks for Second Language Instruction. In Crookes, G. and Gass, S. M (Eds.), Tasks and Language Learning: Integrating Theory and Practice. Clevedon, Avon: Multilingual Matters, Ltd.

Prabhu, N. S. 1987. Second Language Pedagogy. Oxford: Oxford University Press.
Seedhouse, P. 1999. Task-based Interaction. ELT Journal, 53(3): 149-155.

Skehan, P. 1998. A Cognitive Approach to Language Learning. Oxford: Oxford University Press.

Skehan, P. 1993. A Framework for the Implementation of Task-based Learning. IATEFL Annual Conference Report.

Steward, E. C. and Bennett, M. J. 1991. American Cultural Patterns: A Crosscultural Perspective. Yarmouth: Intercultural Press, Inc.

Tickoo, M. L. 1996. Task-based teaching for Acquisition-poor Environments: Forward and Away from Bangalore. In Kenny, B. and Savage, W. (Eds.), Language and Development: Teachers in a Changing World. London: Longman. 